\title{
Determinants of Green Brand Trust and the Mediating Role of \\ Green Brand Satisfaction \\ Angel Sharma ${ }^{\star}$ and Phadindra Kumar Paudel ${ }^{\star}$
}

\begin{abstract}
This research attempts to examine how perceived green brand quality and perceived performance influences customers trust in green brands through enhancing brand satisfaction. Using a sample of 108 customers in Hong Kong who were observed buying green tissue products, we investigate the relationship of perceived green brand quality and perceived performance with green brand trust, and the mediating effects of green brand satisfaction on these relationships. The results show that perceived green brand quality and perceived performance positively contribute to green brand trust directly and green brand satisfaction is an effective mechanism through which perceived green brand quality and perceived performance promote trust in a green brand.
\end{abstract}

Key Words: perceived green brand quality, perceived performance, green brand satisfaction, green brand trust

${ }^{\star}$ Faculty of Research Methodology, Nepal College of Management, Kathmandu University. Email: angel.sharmact@gmail.com

**Faculty of Financial Accounting, Nepal College of Management, Kathmandu University. Email: phadindrapaudel100@gmail.com 


\section{Introduction}

The notion of 'becoming green' is gaining popularity, as depicted in the 2012 survey by National Geographic, where $56 \%$ of the people described themselves as green (Gershoff and Frels, 2015). As a result, green products have increased across markets in recent times (Liu et al., 2012). Green products can be defined as those products that are are more ecological than their alternatives, for example using recycled materials, (Ottman, 1998; Chowdhury and Samuel, 2014) or Kwon et al., (2016, p. 815) state "green products reduce the use of natural resources and toxic materials as well as the emissions of waste and pollutants in their use and disposal". Firms increasingly receive benefits from green products in the marketplace (Lin and Chang, 2012). Along with the surge of green products in the market, there has been a parallel focus on green marketing, as consumers have been responding to brands that promote environmental responsibility (Olsen et al., 2014; Bailey et al., 2016). Yet, some research show that consumers are still reluctant to buy green products primarily because of the perceived inferiority of these products (Olson, 2013); the premium prices of green products over traditional products (Moser, 2015); the past exaggeration of firms concerning their environmental performance (Kalafatis et al., 1999; Olson, 2013) or due to uncertainty arising from having to adopt products which might not be in congruence with their current knowledge structure (Majid and Russell, 2015).

Various brands have resorted to the use of third-party ratings and eco-seals from independent organisations (e.g. government agencies, environmental standards agencies etc.) in a bid to communicate the greenness of their brand (Ottman et al., 2006). However, since there are a number of labels and product information, consumers become confused about which ratings to trust and therefore become even more sceptical about use of brands that claim to be green (Kwon et al., 2016). Moreover, compared to traditional products customers are not always as familiar with green products, and the decision making process can be influenced heavily against green brands especially when it is a first time purchase (Schiffman et al., 2013). As a result, even the brands that communicate relevant and sufficiently detailed information regarding the benefits of green products (Hartmann and Apaolaza-Ibáñez, 2012), are finding it difficult to reach out to consumers when confronted with growing scepticism and uncertainty. Consumers are aware of greenwashing or the practice of using vague, unsubstantiated and misleading environmental claims by companies (Fernando et al., 2014), that they see eco-seals and third-party ratings with greater doubt than ever before. Some people are also highly critical about use of green products. Building green brand trust is important as it influences not only customers' buy 
Angel Sharma and Phadindra Kumar Paudel: Determinants of Green Brand Trust and the Mediating Role of Green Brand Satisfaction 3

behaviour but also marketers who attempt to achieve the superior performance of the brand.

Environmentally conscious consumers are more likely to search for unique brands that carry their environmental values and address their green needs (Griskevicius et al., 2010). However, it is still unclear what factors play major roles in the decision-making of environmentally conscious customers (Moser, 2015). Some of the reasons outlined above (for example, green washing) might also hold true with environmentally conscious consumers. In the light of various issues, the fundamental question that remains is how can brands that sell green products gain trust from consumers?

Prior research suggested that once consumers generate a sense of benefit from using green products, they will continue to generate a sense of resistance towards such products (Luchs et al., 2010). Customers rely on brand's quality and potential benefits to infer their brand satisfaction. Moreover, brand satisfaction and brand trust are important in developing brand-customer relationships (Ha and Perks, 2005; Zboja and Voorhees, 2006). In other words, customers establish relationships with green brands by considering their brand quality, brand performance, brand satisfaction and brand trust. Therefore, it is necessary to further examine the relationships among these factors in order to address the research gap identified above.

Using the context of consumables, particularly several tissue brands, which meet the operational definition of green products and are marketed as such (i.e. they are biodegradable, made from recycled products, and are non-toxic), this paper attempts to examine (1) how perceived green brand quality and perceived performance enhance green brand satisfaction and green brand trust and (2) how green brand satisfaction plays a role to positively link perceived green brand quality and performance with green brand trust.

The remainder of this paper is organised as follows. In Section 2, we reviewed the literature pertinent to the factors which we are considering in this study and developed the research hypothesis. We then presented the methods in Section 3, and demonstrated the analysis and corresponding results in Section 4. Finally, Section 5 presents our findings, the implications of this study for managers and practitioners, the limitations of this research and the conclusion. 


\section{Theoretical Background and Hypothesis Development}

\section{The effect of perceived green brand quality on green brand trust}

Brand trust can be defined as the willingness of the consumer to rely on the brand in which they have confidence in (Moorman et al., 1993). Brand trust is a culmination of psychological connection between the consumer and the manufacturer, whereby, the consumer believes in the brand's capability to communicate their identity (Xie et al., 2015). Green brand trust is the willingness of a consumer to depend on a brand based on the belief or expectation resulting from its credibility, benevolence and ability about its environmental performance (Chen, 2010). Brand trust plays an instrumental role, especially, with the marketing of green products for several reasons. First, in the relationship-marketing literature, trust has been viewed as a determinant of loyalty and brand attractiveness, especially, because trust plays a crucial role in fostering long-term relationships between customers and brands (Viktoria Rampl and Kenning, 2014; Jin et al., 2013). Green brands that secure trust from their consumers will benefit from long-term relationships as consumers will be inclined to buy their products because of the trust that they will have developed. Second, trust is consistently related to vulnerability and serves as an economising tool to reduce complexity and uncertainty (Sanchez-Franco, 2009). Compared to traditional products, customers are faced with uncertainty when it comes to accepting green products, given their novelty. If green brands are able to secure trust from their consumers, they will be able to alleviate concerns of uncertainty arising from having to adopt their relatively 'new' product compared to the traditional alternative. Third, trust in a brand can cause positive behavioural consequences (Luk and Yip, 2008; Limbu et al., 2012). Green brands that can secure trust from their customers will be rewarded with repeated purchases, which is a positive behavioural consequence.

Perceived brand quality can be defined as the customer's evaluation of the superiority or excellence of a brand with regards to its intended objectives (Parasuraman et al., 1988; Ng et al., 2014) and represents an influential driver of consumers initial identification with a brand (Lam et al., 2013). When customers perceive superior brand quality, excellent brand reputation and positive brand image are generated (Fisk et al., 2011). Perceived green brand quality also enhances green brand trust through several ways. Customers believe that green brands are less effective that traditional products and will therefore, have to consume greater quantities to obtain the same effect arising from the use of non-green products (Lin and Chang, 2012). However, if the perceived quality of green products, are similar or better than traditional products, consumers begin to form trust 
Angel Sharma and Phadindra Kumar Paudel: Determinants of Green Brand Trust and the Mediating Role of Green Brand Satisfaction 5 in the brand and ultimately it affects their intention to purchase (Tseng and Hung, 2013; Chen and Chang, 2013b). Further, a brand which is known and linked with superior quality tends to build a positive mental image which in turn influences customer attitude towards the brand (Müge Arslan and Korkut Altuna, 2010). This positive mental image leads to a psychological relationship with the brand, and culminates in brand trust as aforementioned. Moreover, perceived quality also influences customer's willingness to pay a premium price (Pappu and Quester, 2008) for green products which are generally more expensive compared to traditional products (Gleim et al., 2013). This willingness to pay a premium price arises out of the trust that they will have built with the brand's offerings. Based on these arguments, we develop our first hypothesis.

\section{H1a: Perceived green brand quality is positively associated with green brand trust. The effects of perceived performance on green brand trust}

Perceived performance can be defined as the customer's predictions of the nature and level of performance that they will received from a product (Woodruff et al., 1983; Churchill Jr and Surprenant, 1982). The expectation of persistently competent performance from an exchange partner in a buyer-seller relationship has been established as an antecedent to development of trust in existing literature (Sirdeshmukh et al., 2002; Smith and Barclay, 1997; Mayer et al., 1995; Dowell et al., 2015; Ha et al., 2016). Perceived performance of a product enhances brand trust due to various reasons. First, a product that performs at the level or above the expected level of performance will result in positive confidence in the brand whilst performance below expectations will result in negative confidence (Selnes, 1993; Fernandes and Neves, 2014). A positive confidence in the brand's offerings leads to establishment of trust in the brand and trust in a brand can lead to repeated purchase of that brand (Chumpitaz Caceres and Paparoidamis, 2007; Badrinarayanan et al., 2012).Second, improved environmental performance and process innovations that increase material efficiency will increase customer demand, whereas, innovations that do not increase efficiency will face reduced customer demand (Pekovic et al., 2016). Consumers who perceive greater environmental performance from a green brand will form a psychological relationship with that brand as that particular brand will not only fulfil their existing demand but also reduce their uncertainty which results in formation of brand trust. Third, the performance of green products has been inferior compared to non-green products in the past (Ottman, 1992; Pickett-Baker and Ozaki, 2008). In the past, brands have also been accused of greenwashing, or marketing through use of "vague, unsubstantiated and potentially misleading environmental claims" (Fernando et al., 2014, 
p. 167). These greenwashing claims have caused people to become more conscious about the performance of green products. Consumers switch to non-green alternatives because of the trade-offs that green products force on their users in terms of higher prices, lower quality and/or reduced performance (Olson, 2013). Focusing on the performance of products will help brands combat greenwashing claims, as they will build trust over time from the customers once they start meeting their performance expectations. Based on these arguments, we build our second hypothesis:

\section{H1b: Perceived performance is positively associated with green brand trust. The mediating effect of green brand satisfaction}

Brand satisfaction is a complex concept which comes about from the psychological and emotional result of individual experiences (Lin, 2015). In other words, it refers to the customer's affective state resulting from an overall appraisal of their experience (Verhoef et al., 2002). Brand trust is defined as "a confident, positive and reliable experience regarding a particular brand” (Han and Sung, 2008, p. 809). It also refers to confidence in an exchange partner's reliability and integrity (Crosby et al., 1990; Wulf et al., 2001; Tracey and Timothy, 2010). Trust encapsulates the belief that a seller will stand by their word and fulfil their promised role obligations (Dwyer et al., 1987; Anderson and Narus, 1990; Tracey and Timothy, 2010). Trust is a prerequisite for brands that seek to maintain a longer-term relationship with their consumers, and enhance their competitive advantage simultaneously (Delgado-Ballester and Luis Munuera-Alemán, 2005). The ultimate goal of marketing is to generate an intense bond between consumer and the brand of which trust is a key factor (Hegner and Jevons, 2016).

As environmental consciousness is more prevalent nowadays (Yu-Shan and ChingHsun, 2012), the notion of green marketing has been widely accepted by scholars and practitioners alike (Chen and Chang, 2013a). Consumers develop their willingness to depend on the brand based on the belief or expectation resulting from its credibility, benevolence and ability about its environmental performance (Chen, 2010). When a customer's environmental desires, sustainable expectations and green needs are fulfilled, its leads to a pleasurable level of consumption-related fulfilment (Chen, 2010) or pleasurable psychological and emotional result. Consistent with the definition, as aforementioned, brand satisfaction is then the ultimate result arising out of such experience. Improving customer satisfaction has become a top priority for many brands today and has been a key issue especially in relationship marketing literature (Burger and Cann, 1995; Rese, 2003). 
Angel Sharma and Phadindra Kumar Paudel: Determinants of Green Brand Trust and the Mediating Role of Green Brand Satisfaction 7

Expectancy/disconfirmation paradigm in process theory (Oliver, 1977; Oliver, 1980), provides the foundation for a majority of satisfaction studies and encompasses four major constructs namely expectations, performance, disconfirmation and satisfaction. A disconfirmation arises when the perceived expectations are not met by the actual product or when there is a discrepancy between prior expectations and actual performance (Tse and Wilton, 1988). When prior expectations of customers are met by the actual performance of the product, this results in satisfaction. Scholars have established that satisfaction has a positive effect on trust based on the rationale that previous satisfying experience becomes a source of trust (for example see Johnson and Grayson, 2005; Selnes, 1998; Román, 2003; Dodds et al., 1991). Consumers are willing to pay for a specific brand as they perceive some unique value in the brand where the uniqueness is derived from greater trust in the reliability or from favourable effects arising from use of the brand (Chaudhuri and Holbrook, 2001). Extant literature echoes the notion that previous brand experiences contribute to customer's brand satisfaction (for example see Brakus et al., 2009; Iglesias et al., 2011).

Based on the idea that customer satisfaction represents a function of expectations and perceived product attributes (Marinkovic et al., 2014) and since perceived performance and perceived brand quality both contribute to brand experiences according to extant literature, we hypothesise that brand satisfaction will mediate the relationship between perceived performance, perceived brand quality and trust. We develop our second hypothesis accordingly and present a conceptual model as follows:

H2: Green brand satisfaction mediates the relationship of (a) perceived green brand quality and (b) perceived brand performance with green brand trust

\section{Figure 1: A conceptual model showing paths to achieving green brand trust.}

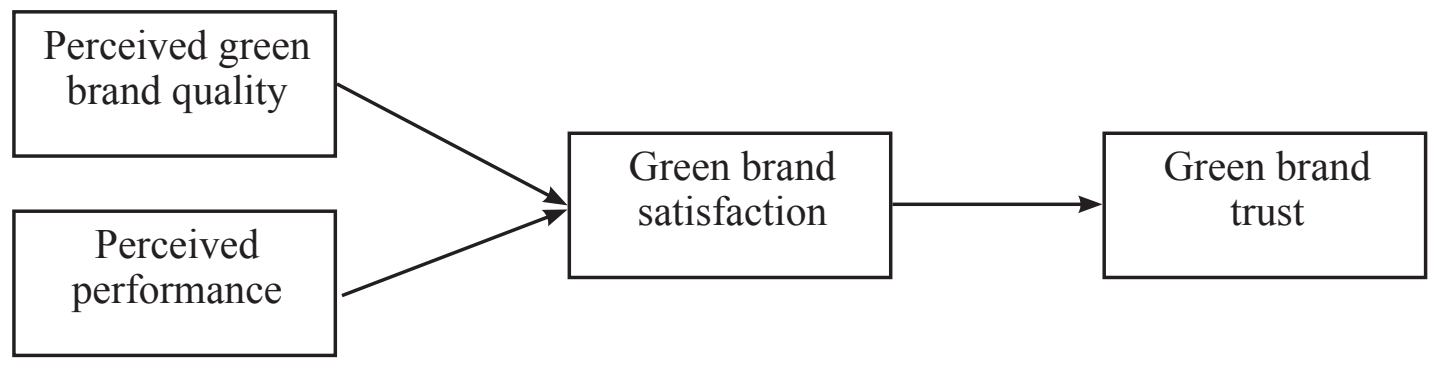




\section{Methods}

\section{Sample and data collection}

To test our hypotheses, we collected data by a questionnaire survey with customers who were randomly observed buying green tissue products in shopping centres in Hong Kong. We selected tissue products because they meet the criteria of green product as they are biodegradable and are not harmful to the people and the planet (SCPA, 2016; Cronin et al., 2011). The questionnaires were developed and refined on the basis of several steps which included pretesting and testing (Gerbing and Anderson, 1988). The questionnaire was drafted in English based on the literature review. This was then translated into Chinese for pre-tests. We then conducted interviews with 16 customers. Based on the results of interviews, we revised the questionnaire and carried out a back-translation procedure to ensure the conceptual equivalence of the English and the Chines versions. Data was collected by personally administrating to potential participants in shopping centres in Hong Kong. The individuals were given a brief introduction of the research purpose. Above $60 \%$ of contacted individuals agreed to participate in the survey. The final usable sample was 108 customers. Table 1 shows the demographics of our respondents.

\section{Tebale 1}

\section{Demographics of the respondents}

\begin{tabular}{lllc}
\hline Demographics & Number of responses & \multicolumn{2}{l}{ Percentage of responses (\%) } \\
\hline Gender & Male & 53 & 49.1 \\
Age & Female & 55 & 50.9 \\
& 18-29 years old & 26 & 24.1 \\
& 30-39 years old & 19 & 17.6 \\
& 40-49 years old & 21 & 19.4 \\
Education & 50-59 years old & 19 & 17.6 \\
& >60 years old & 23 & 21.3 \\
& Primary level & 17 & 15.7 \\
& High School level & 50 & 46.3 \\
& Diploma/Higher Diploma level & 7 & 6.5 \\
& Associates degree & 5 & 4.6 \\
& Bachelor degree & 14 & 13 \\
Occupation & Postgraduate & 15 & 13.9 \\
& Student & 28 & 25.9 \\
& Blue collar worker & 10 & 9.3 \\
\hline
\end{tabular}


Angel Sharma and Phadindra Kumar Paudel: Determinants of Green Brand Trust and the Mediating Role of Green Brand Satisfaction 9

\begin{tabular}{|c|c|c|c|}
\hline \multirow{9}{*}{ Income } & White collar worker & 39 & 36.1 \\
\hline & Managerial level & 29 & 26.9 \\
\hline & Housewife & 1 & 0.9 \\
\hline & Unemployed & 1 & 0.9 \\
\hline & $<\$ 6333$ & 37 & 34.3 \\
\hline & $\$ 6333-\$ 10000$ & 38 & 35.2 \\
\hline & $\$ 10000-\$ 25000$ & 15 & 13.9 \\
\hline & $\$ 25000-\$ 50000$ & 12 & 11.1 \\
\hline & $>\$ 50000$ & 6 & 5.6 \\
\hline
\end{tabular}

Measures

Green brand trust refers to the willingness of a customer to buy a product of a brand that they have confidence in. Drawing on prior research (Ha and Perks, 2005; Sirdeshmukh et al., 2002), as shown in Table 2, we measured green brand trust with five items on a 7-point Likert scale ranging from $1=$ "strongly disagree" to $7=$ "strongly agree" $(\alpha=0.90)$. This scale captures the extent to which the customers trust the brand of the products they are buying.

Table 2

Measurement items and validity assessment

Standardised

Factor Load-

Construct with underlying items ings

Green brand trust (Cronbach's $\alpha=0.90, \mathrm{CR}=0.89, \mathrm{AVE}=0.62$, $\mathrm{MSV}=\mathbf{0 . 5 1}, \mathrm{ASV}=\mathbf{0 . 3 7}$ )

$\begin{array}{ll}\text { The company of the brand I am evaluating is dependable. } & 0.74\end{array}$

$\begin{array}{ll}\text { The company of the brand I am evaluating is honest. } & 0.68\end{array}$

I rely on the company of the brand I am evaluating. $\quad 0.75$

The company of the brand I am evaluating is a safe company with which to conduct business.

I consider the company of the brand I am evaluating to be generally trustworthy.

Perceived green brand quality (Cronbach's $\alpha=0.85, \mathrm{CR}=0.84$, $\mathrm{AVE}=0.57, \mathrm{MSV}=0.38, \mathrm{ASV}=0.27$ ) 
I expect certain superior performance from my favourite brand of tissue.

I expect trouble-free performance from my favourite brand.

I have positive personal feelings towards my favourite brand.

After using the brand that I like for the first time, I have grown fond of it.

\section{Perceived performance (Cronbach's $\alpha=0.90, C R=0.91$,} $\mathrm{AVE}=0.71, \mathrm{MSV}=0.37, \mathrm{ASV}=\mathbf{0 . 3 1})$

I believe that the brand I like performs better than competing brands in market development.

I believe that the brand I like performs better than competing brands in attracting customers.

I believe that the brand I like performs better than competing brands in market share.

I believe that the brand I like performs better than competing brands in profitability.

Green brand satisfaction (Cronbach's $\alpha=0.85, \mathrm{CR}=0.87$, $\mathrm{AVE}=0.67, \mathrm{MSV}=0.51, \mathrm{ASV}=0.41$ )

The brand is exactly what I need

0.73

Using the brand has been good experience

0.85

I am satisfied with my decision to buy this brand

0.86

Perceived green brand quality refers to the customer's evaluation surrounding the excellence of a brand in terms of quality. We drew on prior research (Smit et al., 2007; Chaudhuri and Holbrook, 2001) and measured perceived green brand quality with four items on a 7-point Likert scale $(\alpha=0.85)$, shown in Table 2. Our scale captures the extent to which the customers perceive the quality in the brand that they are buying.

Perceived performance refers to the level of performance that customers expect from a brand. We drew on prior research (O'Cass and Ngo, 2007) and measured perceived performance, as shown in Table 2, with four items on a 7 point Likert scale $(\alpha=0.90)$. The scale that we use captures the extent to which the customers perceive the level of performance of the brand that they are buying. 
Angel Sharma and Phadindra Kumar Paudel: Determinants of Green Brand Trust and the Mediating Role of Green Brand Satisfaction 11

Similarly, green brand satisfaction refers to the positive overall experience of the brand that the customers buy. We drew on prior literature (Bennett, Härtel, and McColl-Kennedy, 2005), and measured brand satisfaction with three measures on a 7 point Likert scale ( $\alpha=$ 0.85). Our scale captures the extent to which customers are satisfied with the brand of the products that they are buying.

\section{Reliability and Validity}

We conducted reliability and validity analysis for all of the measures that were used to test our hypotheses. Reliability was assessed with Cronbach's alphas and composite reliabilities (CRs). The results in Table 2 show that the Cronbach alphas for each construct ranged from 0.85 to 0.90 and the CRs ranged from 0.84 to 0.91 , indicating adequate reliability. We tested validity with confirmatory factor analysis (CFA). The results show that the CFA of a four-construct model has a good fit with the data $\left(\chi^{2}=117.293, \chi^{2} / \mathrm{df}=1.197, \mathrm{CFI}=0.982\right.$, $\mathrm{IFI}=0.983$, TLI=0.978, RMSEA=0.043). Moreover, all the items load significantly ( $\mathrm{p}<$ 0.001 ) on their corresponding construct with acceptable values of standardised factor loadings (0.63-0.91) and the average variance extracted (AVE) values (0.57-0.71) were all above the 0.5 cut-off (Fornell and Larcker, 1981). These results provide evidence for convergent validity. The results in Table 1 also show discriminant validity using MSV and AVE values, where MSV $<$ AVE and ASV $<$ AVE. Moreover, the square root of AVEs in Table 2 was also found to be greater than inter-constructs relations providing further evidence for discriminant validity (Fornell and Larcker, 1981).

\section{Results}

Table 3 presents descriptive statistics and correlations for the major variables. As expected, perceived green brand quality was found to be positively correlated with green brand satisfaction $(r=0.577, \mathrm{p}<0.001)$ and green brand trust $(\mathrm{r}=0.489, \mathrm{p}<0.001)$. Similarly, correlations of perceived performance with green brand satisfaction $(\mathrm{r}=0.535, \mathrm{p}<0.001)$ and green brand trust $(\mathrm{r}=0.509, \mathrm{p}<0.001)$ were also significantly positive.

Table 3

Descriptive statistics and correlations

\begin{tabular}{lccrrrr}
\hline & Mean & $\begin{array}{l}\text { Std } \\
\text { Dev }\end{array}$ & 1 & 2 & 3 & 4 \\
\hline $\begin{array}{l}\text { 1. Green brand trust } \\
\begin{array}{l}\text { 2. Perceived green brand } \\
\text { quality }\end{array}\end{array}$ & 4.522 & 0.792 & $\mathbf{0 . 7 8 7}$ & & \\
\end{tabular}


3. Perceived performance $\quad 4.660 \quad 0.851 \quad 0.509 * * * \quad 0.365^{* * *} \quad \mathbf{0 . 8 4 3}$

$\begin{array}{lllllll}\text { 4. Green brand satisfaction } & 4.787 & 0.911 & 0.652 * * * & 0.577 * * * & 0.535 * * * & \mathbf{0 . 8 1 9}\end{array}$

Significance levels: † $\mathrm{p}<0.10$; ${ }^{*} \mathrm{p}<0.05 ;{ }^{* *} \mathrm{p}<0.01$, ${ }^{* *} \mathrm{p}<0.001$

The bold numbers on the diagonal represent the square root of AVEs.

Hypothesis 1a predicts that perceived green brand quality positively affects green brand trust. Figure 2 (a) shows the direct relationship between perceived green brand quality and green brand trust. The results show that perceived green brand quality is significantly and positively related to green brand trust $(\beta=0.467, \mathrm{p}<0.001)$. Thus, hypothesis $1 \mathrm{a}$ is supported.

\section{Figure 2: Results of direct and indirect effects for mediation.}

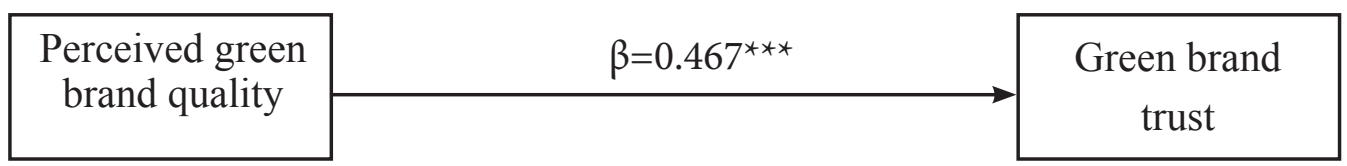

a: The direct effect of perceived green brand quality on brand trust.

Significance levels: $\uparrow \mathrm{p}<0.10 ;{ }^{\star} \mathrm{p}<0.05 ;{ }^{\star *} \mathrm{p}<0.01,{ }^{\star *} \mathrm{p}<0.001$

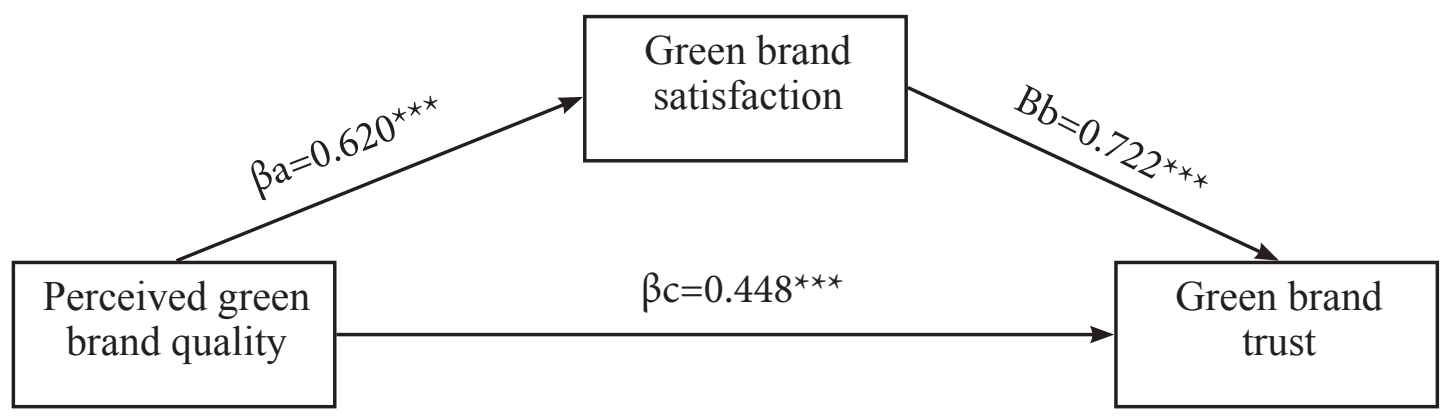

b: Path coefficients for the relationship of perceived green brand quality, green brand satisfaction and green brand trust. The mediated effect of green brand satisfaction on the relationship of perceived green brand quality with green brand trust is represented by $\beta c$. Significance levels: $\uparrow_{p}<0.10 ;{ }^{\star} \mathrm{p}<0.05 ;{ }^{* *} \mathrm{p}<0.01,{ }^{* *} \mathrm{p}<0.001$

\begin{tabular}{|c|c|c|c|}
\hline $\begin{array}{c}\text { Perceived } \\
\text { performance }\end{array}$ & $\beta=0.592^{\star * *}$ & $\begin{array}{c}\text { Green brand } \\
\text { trust }\end{array}$ \\
\cline { 2 - 3 }
\end{tabular}


c: The direct effect of perceived performance on green brand trust.

Significance levels: ${ }^{\top} \mathrm{p}<0.10 ;{ }^{\star} \mathrm{p}<0.05 ;{ }^{* \star} \mathrm{p}<0.01$, ${ }^{\star * \star} \mathrm{p}<0.001$

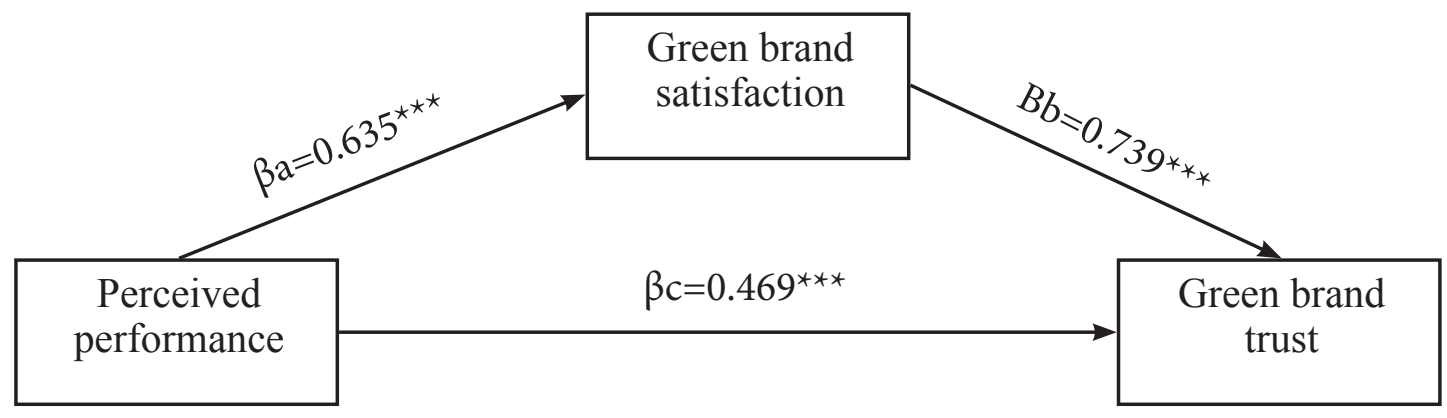

d: Path coefficients for the relationship of perceived performance, green brand satisfaction and green brand trust. The mediated effect of green brand satisfaction on the relationship of perceived green brand quality with green brand trust is represented by $\beta c$. Significance levels: $\uparrow_{p}<0.10 ;{ }^{*} \mathrm{p}<0.05 ;{ }^{* *} \mathrm{p}<0.01$, ${ }^{* *} \mathrm{p}<0.001$

Similarly, Hypothesis $1 \mathrm{~b}$ predicts that perceived performance positively affects green brand trust. The results in Figure 2(c) show that perceived performance is significantly and positively related to green brand trust $(\beta=0.592, \mathrm{p}<0.001)$. Thus, hypothesis $1 \mathrm{~b}$ is supported.

Hypothesis 2 predicts that green brand satisfaction mediates the relationship of perceived green brand quality and perceived performance with green brand trust.. The results in Table 4 show that the indirect effects of perceived green brand quality and perceived performance on green brand trust are 0.580 and 0.566 respectively. Moreover, the results of Sobel, (1982)'s z-test suggest that the indirect effects of both perceived green brand quality $(\mathrm{z}=2.654, \mathrm{p}<0.01)$ and perceived performance $(\mathrm{z}=3.070, \mathrm{p}<0.01)$ with green brand trust are significant and the $95 \%$ bootstrapped confidence intervals for these two indirect effects also did not contain zero(for perceived green brand quality: LCI $=0.298$, $\mathrm{UCI}=0.977$; for perceived performance: $\mathrm{LCI}=0.282, \mathrm{UCI}=0.809$ ). These results confirm that green brand satisfaction is a mediator on the relationships of perceived green brand quality and perceived performance with green brand trust. On the other hand, the results in Figure $2 \mathrm{~b}$ and $2 \mathrm{~d}$ demonstrate that the direct relationships of perceived green brand quality $(\beta=0.467, \mathrm{p}<0.001)$ and perceived performance $(\beta=0.592, \mathrm{p}<0.001)$ with green brand trust are still significant when controlling for grand brand satisfaction suggesting that green brand satisfaction is a partial mediator in the relationships of perceived green brand quality and perceived performance with green brand trust. Thus, Hypothesis 2 is supported. 
Table 4

Results of Sobel and Bootstrapping for mediation effect

\begin{tabular}{llcccc}
\hline & & Unstandardized & LCI & UCI & Z \\
\hline \multirow{2}{*}{$\begin{array}{l}\text { Indirect } \\
\text { effect }\end{array}$} & value & $95 \%$ & $95 \%$ & \\
& $\begin{array}{l}\text { Perceived green brand } \\
\text { quality }\end{array}$ & 0.580 & 0.298 & 0.977 & $2.654^{* *}$ \\
& $\begin{array}{l}\text { Perceived Perfor- } \\
\text { mance }\end{array}$ & 0.566 & 0.282 & 0.809 & $3.070^{* *}$ \\
\hline
\end{tabular}

LCI = Lower confidence interval. UCI=Upper confidence Interval

Significance levels: ${ }^{\top} \mathrm{p}<0.10 ;{ }^{*} \mathrm{p}<0.05 ;{ }^{* *} \mathrm{p}<0.01,{ }^{* *} \mathrm{p}<0.001$

\section{Discussion and Conclusion}

Green marketing is becoming one of the trends for companies. The main challenge for green brands is to raise green trust while huge scepticism surrounding their environmental performance still exists. The purpose of this research is to investigate how brand trust can be built for green products. While a body of research has examined branding issues, there has been a lack of research in the context of green products. This research developed a conceptual framework to fill this research gap by investigating the direct and indirect effects of perceived green brand quality, perceived performance and green brand satisfaction on green brand trust.

Our findings suggest that both perceived green brand quality and performance positively contribute to green brand trust. In other words, our findings provide evidence that if customers perceive a green brand as high quality and better performance; they lead to trust in the green brand. Based on the findings, firms should develop necessary capabilities to increase green brand's quality and performance to establish green brand trust. Furthermore, our results also show that grand brand satisfaction partially mediates the relationships of perceived green brand quality and performance with green brand trust. This interesting finding suggests that perceived green brand quality and performance and green brand satisfaction are complementary in building green brand trust. While they, in and of themselves, contribute significantly to green brand trust respectively, they often work in conjunction with each other to generate a beneficial combination for building green brand trust. Therefore, firms are advised to first focus on increasing green brand quality and performance, and then increase customers' satisfaction with the green brand, which in turn builds green brand trust.

This research has some limitations that need for future research. First, our research 
Angel Sharma and Phadindra Kumar Paudel: Determinants of Green Brand Trust and the Mediating Role of Green Brand Satisfaction 15 captured the value of green brand satisfaction in linking perceived green brand quality and performance with green brand trust. However, some other factors such as brand image are also important in green marketing, Future research should incorporate different mechanisms to examine their uniqueness and similarity when reacting to the effects of green brand quality and performance. Second, our research only investigated green tissues buyers. Future research may benefit from testing the conceptual framework developed in this research with different green products buyers. Third, the use of cross sectional data precludes the test of dynamic change of green brand quality, performance, green brand satisfaction and green brand trust. Future research could conduct longitudinal studies to further explore the causal and dynamic relationships between green brand quality, performance, satisfaction and trust. Finally, the current research is based on perceptionbased constructs to measure perceived green brand quality, perceived performance, green brand satisfaction and green brand trust. Although we conducted an appropriate analysis to assess the validity of these measurements, future research may incorporate alternative measures based on objective data (such as continuous measures) to examine if the findings generated by the current research still hold.

In conclusion, this research contributes to the green marketing literature by extending prior research towards investigation on mechanisms for building green brand trust. Our findings suggest that both perceived green brand quality and performance are important contributors to green brand trust. Moreover, green brand satisfaction serves as an important mechanism to effectively link green brand quality and performance with customers' trust in green brand. These findings help us better understand of how customers' trust in green brand is developed through green brand quality, performance and green brand satisfaction.

\section{References}

Anderson, J. C. and Narus, J. A. (1990). A model of distributor firm and manufacturer firm working partnerships. the Journal of Marketing, pp.42-58.

Badrinarayanan, V., Becerra, E. P., Kim, C.-H. and Madhavaram, S. (2012). Transference and congruence effects on purchase intentions in online stores of multi-channel retailers: Initial evidence from the us and south korea. Journal of the Academy of Marketing Science, 40, pp.539-557. 
Bailey, A. A., Mishra, A. and Tiamiyu, M. F. (2016). Green consumption values and indian consumers' response to marketing communications. Journal of Consumer Marketing, 33 , pp.562-573.

Brakus, J. J., Schmitt, B. H. and Zarantonello, L. (2009). Brand experience: What is it? How is it measured? Does it affect loyalty? Journal of marketing, 73, pp.52-68.

Burger, P. C. and Cann, C. W. (1995). Post-purchase strategy: A key to successful industrial marketing and customer satisfaction. Industrial Marketing Management, 24, pp.9198.

Chaudhuri, A. and Holbrook, M. B. (2001). The chain of effects from brand trust and brand affect to brand performance: The role of brand loyalty. Journal of marketing, 65, pp.81-93.

Chen, Y.-S. (2010). The drivers of green brand equity: Green brand image, green satisfaction, and green trust. Journal of Business Ethics, 93, pp.307-319.

Chen, Y.-S. and Chang, C.-H. (2013a). Greenwash and green trust: The mediation effects of green consumer confusion and green perceived risk. Journal of Business Ethics, 114, pp.489-500.

Chen, Y.-S. and Chang, C.-H. (2013b). Towards green trust: The influences of green perceived quality, green perceived risk, and green satisfaction. Management Decision, 51, pp.63-82.

Chowdhury, P. and Samuel, M. S. (2014). Artificial neural networks: A tool for understanding green consumer behavior. Marketing Intelligence \& Planning, 32, pp.552-566.

Chumpitaz Caceres, R. and Paparoidamis, N. G. (2007). Service quality, relationship satisfaction, trust, commitment and business-to-business loyalty. European journal of marketing, 41, pp.836-867.

Churchill Jr, G. A. and Surprenant, C. (1982). An investigation into the determinants of 
Angel Sharma and Phadindra Kumar Paudel: Determinants of Green Brand Trust and the Mediating Role of Green Brand Satisfaction 17 customer satisfaction. Journal of marketing research, pp.491-504.

Cronin, J. J., Smith, J. S., Gleim, M. R., Ramirez, E. and Martinez, J. D. (2011). Green marketing strategies: An examination of stakeholders and the opportunities they present. Journal of the Academy of Marketing Science, 39, pp.158-174.

Crosby, L. A., Evans, K. R. and Cowles, D. (1990). Relationship quality in services selling: An interpersonal influence perspective. The journal of marketing, pp.68-81.

Delgado-Ballester, E. and Luis Munuera-Alemán, J. (2005). Does brand trust matter to brand equity? Journal of product \& brand management, 14, pp.187-196.

Dodds, W. B., Monroe, K. B. and Grewal, D. (1991). Effects of price, brand, and store information on buyers' product evaluations. Journal of marketing research, pp.307319.

Dowell, D., Morrison, M. and Heffernan, T. (2015). The changing importance of affective trust and cognitive trust across the relationship lifecycle: A study of business-tobusiness relationships. Industrial Marketing Management, 44, pp.119-130.

Dwyer, F. R., Schurr, P. H. and Oh, S. (1987). Developing buyer-seller relationships. The Journal of marketing, pp.11-27.

Fernandes, T. and Neves, S. (2014). The role of servicescape as a driver of customer value in experience-centric service organizations: The dragon football stadium case. Journal of Strategic Marketing, 22, pp.548-560.

Fernando, A. G., Suganthi, L. and Sivakumaran, B. (2014). If you blog, will they follow? Using online media to set the agenda for consumer concerns on "greenwashed" environmental claims. Journal of Advertising, 43, pp.167-180.

Fisk, R. P., Patricio, L., Järvinen, R. and Suomi, K. (2011). Reputation attributes in retailing services: Managerial perspective. Managing Service Quality: An International Journal, 21, pp.410-423.

Fornell, C. and Larcker, D. F. (1981). Structural equation models with unobservable 
18 The International Research Journal of Management Sceince Vol.3 No. 1 December 2018/ISSN 2542-2510 variables and measurement error: Algebra and statistics. Journal of marketing research, pp.382-388.

Gerbing, D. W. and Anderson, J. C. (1988). An updated paradigm for scale development incorporating unidimensionality and its assessment. Journal of marketing research, pp.186-192.

Gershoff, A. D. and Frels, J. K. (2015). What makes it green? The role of centrality of green attributes in evaluations of the greenness of products. Journal of Marketing, 79, pp.97-110.

Gleim, M. R., Smith, J. S., Andrews, D. and Cronin Jr, J. J. (2013). Against the green: A multi-method examination of the barriers to green consumption. Journal of Retailing, 89, pp.44-61.

Griskevicius, V., Tybur, J. M. and Van Den Bergh, B. (2010). Going green to be seen: Status, reputation, and conspicuous conservation. Journal of personality and social psychology, 98, pp.392.

Ha, H.-Y., Lee, M.-S. and Janda, S. (2016). Effects of economic and social satisfaction on partner trust: An investigation of temporal carryover effects. European Journal of Marketing, 50, pp.100-123.

Ha, H.-Y. and Perks, H. (2005). Effects of consumer perceptions of brand experience on the web: Brand familiarity, satisfaction and brand trust. Journal of Consumer Behaviour, 4, pp.438-452.

Han, S.-L. and Sung, H.-S. (2008). Industrial brand value and relationship performance in business markets-a general structural equation model. Industrial Marketing Management, 37, pp.807-818.

Hartmann, P. and Apaolaza-Ibáñez, V. (2012). Consumer attitude and purchase intention toward green energy brands: The roles of psychological benefits and environmental concern. Journal of Business Research, 65, pp.1254-1263. 
Angel Sharma and Phadindra Kumar Paudel: Determinants of Green Brand Trust and the Mediating Role of Green Brand Satisfaction 19

Hegner, S. M. and Jevons, C. (2016). Brand trust: A cross-national validation in germany, india, and south africa. Journal of Product \& Brand Management, 25, pp.58-68.

Iglesias, O., Singh, J. J. and Batista-Foguet, J. M. (2011). The role of brand experience and affective commitment in determining brand loyalty. Journal of Brand Management, 18 , pp.570-582.

Jin, N., Line, N. D. and Goh, B. (2013). Experiential value, relationship quality, and customer loyalty in full-service restaurants: The moderating role of gender. Journal of Hospitality Marketing \& Management, 22, pp.679-700.

Johnson, D. and Grayson, K. (2005). Cognitive and affective trust in service relationships. Journal of Business research, 58, pp.500-507.

Kalafatis, S. P., Pollard, M., East, R. and Tsogas, M. H. (1999). Green marketing and ajzen's theory of planned behaviour: A cross-market examination. Journal of consumer marketing, 16, pp.441-460.

Kwon, W.-S., Englis, B. and Mann, M. (2016). Are third-party green-brown ratings believed?: The role of prior brand loyalty and environmental concern. Journal of Business Research, 69, pp.815-822.

Lam, S. K., Ahearne, M., Mullins, R., Hayati, B. and Schillewaert, N. (2013). Exploring the dynamics of antecedents to consumer-brand identification with a new brand. Journal of the Academy of Marketing Science, 41, pp.234-252.

Limbu, Y. B., Wolf, M. and Lunsford, D. (2012). Perceived ethics of online retailers and consumer behavioral intentions: The mediating roles of trust and attitude. Journal of Research in Interactive Marketing, 6, pp.133-154.

Lin, Y.-C. and Chang, C.-C. A. (2012). Double standard: The role of environmental consciousness in green product usage. Journal of Marketing, 76, pp.125-134.

Lin, Y. H. (2015). Innovative brand experience's influence on brand equity and brand satisfaction. Journal of Business Research, 68, pp.2254-2259. 
Liu, S., Kasturiratne, D. and Moizer, J. (2012). A hub-and-spoke model for multidimensional integration of green marketing and sustainable supply chain management. Industrial Marketing Management, 41, pp.581-588.

Luchs, M. G., Naylor, R. W., Irwin, J. R. and Raghunathan, R. (2010). The sustainability liability: Potential negative effects of ethicality on product preference. Journal of Marketing, 74, pp.18-31.

Luk, S. T. and Yip, L. S. (2008). The moderator effect of monetary sales promotion on the relationship between brand trust and purchase behaviour. Journal of Brand Management, 15, pp.452-464.

Majid, K. A. and Russell, C. A. (2015). Giving green a second thought: Modeling the value retention of green products in the secondary market. Journal of Business Research, 68, pp.994-1002.

Marinkovic, V., Senic, V., Ivkov, D., Dimitrovski, D. and Bjelic, M. (2014). The antecedents of satisfaction and revisit intentions for full-service restaurants. Marketing Intelligence \& Planning, 32, pp.311-327.

Mayer, R. C., Davis, J. H. and Schoorman, F. D. (1995). An integrative model of organizational trust. Academy of management review, 20, pp.709-734.

Moorman, C., Deshpande, R. and Zaltman, G. (1993). Factors affecting trust in market research relationships. the Journal of Marketing, pp.81-101.

Moser, A. K. (2015). Thinking green, buying green? Drivers of pro-environmental purchasing behavior. Journal of Consumer Marketing, 32, pp.167-175.

Müge Arslan, F. and Korkut Altuna, O. (2010). The effect of brand extensions on product brand image. Journal of Product \& Brand Management, 19, pp.170-180.

Ng, P. F., Butt, M. M., Khong, K. W. and Ong, F. S. (2014). Antecedents of green brand equity: An integrated approach. Journal of Business Ethics, 121, pp.203-215. 
O'cass, A. and Ngo, L. V. (2007). Balancing external adaptation and internal effectiveness: Achieving better brand performance. Journal of Business Research, 60, pp.11-20.

Oliver, R. L. (1977). Effect of expectation and disconfirmation on postexposure product evaluations: An alternative interpretation. Journal of applied psychology, 62, pp.480.

Oliver, R. L. (1980). A cognitive model of the antecedents and consequences of satisfaction decisions. Journal of marketing research, pp.460-469.

Olsen, M. C., Slotegraaf, R. J. and Chandukala, S. R. (2014). Green claims and message frames: How green new products change brand attitude. Journal of Marketing, 78, pp.119-137.

Olson, E. L. (2013). It's not easy being green: The effects of attribute tradeoffs on green product preference and choice. Journal of the Academy of Marketing Science, 41, pp.171-184.

Ottman, J. A. (1992). Industry's response to green consumerism. Journal of Business Strategy, 13, pp.3-7.

Ottman, J. A. (1998). Green marketing: Opportunity for innovation, New York, NTC Business Books.

Ottman, J. A., Stafford, E. R. and Hartman, C. L. (2006). Avoiding green marketing myopia: Ways to improve consumer appeal for environmentally preferable products. Environment: Science and Policy for Sustainable Development, 48, pp.22-36.

Pappu, R. and Quester, P. G. (2008). Does brand equity vary between department stores and clothing stores? Results of an empirical investigation. Journal of Product \& Brand Management, 17, pp.425-435.

Parasuraman, A., Zeithaml, V. A. and Berry, L. L. (1988). Servqual. Journal of retailing, 64, pp.12-40. 
Pekovic, S., Rolland, S. and Rudd, J. (2016). Customer orientation and firm's business performance: A moderated mediation model of environmental customer innovation and contextual factors. European Journal of Marketing, 50.

Pickett-Baker, J. and Ozaki, R. (2008). Pro-environmental products: Marketing influence on consumer purchase decision. Journal of consumer marketing, 25, pp.281-293.

Rese, M. (2003). Relationship marketing and customer satisfaction: An information economics perspective. Marketing theory, 3, pp.97-117.

Román, S. (2003). The impact of ethical sales behaviour on customer satisfaction, trust and loyalty to the company: An empirical study in the financial services industry. Journal of Marketing Management, 19, pp.915-939.

Sanchez-Franco, M. J. (2009). The moderating effects of involvement on the relationships between satisfaction, trust and commitment in e-banking. Journal of Interactive Marketing, 23, pp.247-258.

Schiffman, L., O'cass, A., Paladino, A. and Carlson, J. (2013). Consumer behaviour, Sydney Pearson Higher Education

Scpa. (2016). The low down on tissue paper breakdown [Online]. Available: http://www. scpa.com.ph/infographics/decomposition-infograhic/ [Accessed 30 November 2016].

Selnes, F. (1993). An examination of the effect of product performance on brand reputation, satisfaction and loyalty. European Journal of Marketing, 27, pp.19-35.

Selnes, F. (1998). Antecedents and consequences of trust and satisfaction in buyer-seller relationships. European journal of marketing, 32, pp.305-322.

Sirdeshmukh, D., Singh, J. and Sabol, B. (2002). Consumer trust, value, and loyalty in relational exchanges. Journal of marketing, 66, pp.15-37.

Smit, E., Bronner, F. and Tolboom, M. (2007). Brand relationship quality and its value for 
Angel Sharma and Phadindra Kumar Paudel: Determinants of Green Brand Trust and the Mediating Role of Green Brand Satisfaction 23 personal contact. Journal of Business Research, 60, pp.627-633.

Smith, J. B. and Barclay, D. W. (1997). The effects of organizational differences and trust on the effectiveness of selling partner relationships. the Journal of Marketing, pp.3-21.

Sobel, M. E. (1982). Asymptotic confidence intervals for indirect effects in structural equation models. Sociological methodology, 13, pp.290-312.

Tracey, S. D. and Timothy, K. O. B. (2010). Does experience matter?: Differences in relationship benefits, satisfaction, trust, commitment and loyalty for novice and experienced service users. European Journal of Marketing, 44, pp.1528-1552.

Tse, D. K. and Wilton, P. C. (1988). Models of consumer satisfaction formation: An extension. Journal of marketing research, pp.204-212.

Tseng, S.-C. and Hung, S.-W. (2013). A framework identifying the gaps between customers' expectations and their perceptions in green products. Journal of cleaner production, 59, pp.174-184.

Verhoef, P. C., Franses, P. H. and Hoekstra, J. C. (2002). The effect of relational constructs on customer referrals and number of services purchased from a multiservice provider: Does age of relationship matter? Journal of the Academy of Marketing Science, 30, pp.202216.

Viktoria Rampl, L. and Kenning, P. (2014). Employer brand trust and affect: Linking brand personality to employer brand attractiveness. European Journal of Marketing, 48, pp.218236.

Woodruff, R. B., Cadotte, E. R. and Jenkins, R. L. (1983). Modeling consumer satisfaction processes using experience-based norms. Journal of marketing research, pp.296-304.

Wulf, K. D., Odekerken-Schröder, G. and Iacobucci, D. (2001). Investments in consumer relationships: A cross-country and cross-industry exploration. Journal of marketing, 65, pp.33-50. 
Xie, Y., Batra, R. and Peng, S. (2015). An extended model of preference formation between global and local brands: The roles of identity expressiveness, trust, and affect. Journal of International Marketing, 23, pp.50-71.

Yu-Shan, C. and Ching-Hsun, C. (2012). Enhance green purchase intentions: The roles of green perceived value, green perceived risk, and green trust. Management Decision, 50, pp.502-520.

Zboja, J. J. and Voorhees, C. M. (2006). The impact of brand trust and satisfaction on retailer repurchase intentions. Journal of Services Marketing, 20, pp.381-390. 